\title{
Analysing deltamethrin susceptibility and pyrethroid esterase activity variations in sylvatic and domestic Triatoma infestans at the embryonic stage
}

\author{
Pablo Luis Santo-Orihuela/ ${ }^{+}$, Guillermo Carvajal, María Inés Picollo, Claudia Viviana Vassena \\ Centro de Investigaciones en Plagas e Insecticidas, Instituto de Investigaciones Científicas y Técnicas para la Defensa, \\ Consejo Nacional de Investigaciones Científicas y Técnicas, Buenos Aires, Argentina
}

The aim of the present work was to study the deltamethrin susceptibility of eggs from Triatoma infestans populations and the contribution of pyrethroid esterases to deltamethrin degradation. Insects were collected from sylvatic areas, including Veinte de Octubre and Kirus-Mayu (Bolivia) and from domiciliary areas, including El Palmar (Bolivia) and La Pista (Argentina). Deltamethrin susceptibility was determined by dose-response bioassays. Serial dilutions of deltamethrin (0.0005-1 $\mathrm{mg} / \mathrm{mL})$ were topically applied to 12-day-old eggs. Samples from El Palmar had the highest lethal dose ratio (LDR) value (44.90) compared to the susceptible reference strain (NFS), whereas the Veinte de Octubre samples had the lowest value (0.50). Pyrethroid esterases were evaluated using 7-coumaryl permethrate (7-CP) on individually homogenised eggs from each population and from NFS. The El Palmar and La Pista samples contained 40.11 and $36.64 \mathrm{pmol} / \mathrm{min} / \mathrm{mg}$ protein, respectively, and these values were statistically similar to NFS (34.92 pmol/min/mg protein) and different from Kirus-Mayu and Veinte de Octubre (27.49 and 22.69 pmol/min/mg protein, respectively). The toxicological data indicate that the domestic populations were resistant to deltamethrin, but no statistical contribution of 7-CP esterases was observed. The sylvatic populations had similar LDR values to NFS, but lower 7-CP esterase activities. Moreover, this is the first study of the pyrethroid esterases on $\mathrm{T}$. infestans eggs employing a specific substrate (7-CP).

Key words: Triatoma infestans - egg - pyrethroid insecticides - pyrethroid esterases

Triatoma infestans (Klug 1834) (Hemiptera, Reduviidae, Triatominae) is the main vector of Trypanosoma cruzi, which is the parasite responsible for causing Chagas disease. At present, this endemic infection affects approximately nine million people in Argentina and Bolivia (Schofield et al. 2006). T. infestans is a haematophagous insect that originally lived in natural foci, but started to colonise houses several thousand years ago. Rural and rustic dwellings provide shelter and food sources for these insects, allowing for the formation of intradomiciliary colonies (Dias \& Schofield 2007). This type of $T$. infestans colony has been successfully controlled in the southern cone of Latin America by spraying houses with pyrethroid insecticides (Dias et al. 2002, Schofield et al. 2006). However, several areas in the Gran Chaco of Argentina, Bolivia and Paraguay have been targeted with intensive vector control efforts without success (Gurtler et al. 2007). Several authors have demonstrated that insects from this region have developed resistance to pyrethroid insecticides (Picollo et al. 2005, Santo-Orihuela et al. 2008, Toloza et al. 2008, Germano et al. 2010, Lardeux et al. 2010, Santo-Orihuela \& Picollo 2011).

doi: 10.1590/0074-0276130184

Financial support: CONICET, RELCOV

+ Corresponding author: psantoorihuela@conicet.gov.ar

Received 3 April 2013

Accepted 26 September 2013
Moreover, a study by Alarico et al. (2010) demonstrated deltamethrin-resistant $T$. infestans populations from this region were susceptible to a micro-encapsulated formulation containing organophosphate insecticides. The development of resistance in this and other regions has led investigators to evaluate the toxicity of non-pyrethroid insecticides against $T$. infestans (Carvajal et al. 2012). Most of these studies were conducted in T. infestans populations from intradomiciliary environments. In addition, some sylvatic populations studied by Lardeux et al. (2010) and Depickère et al. (2012) demonstrated deltamethrin toxicity based on toxicological analyses of topical insecticide applications. Roca-Acevedo et al. (2011) recently focused on the relevance of cytochrome P450 monooxygenases and pyrethroid esterases in first instar nymphs, while Santo-Orihuela et al. (2013) studied the detoxification activity of glutathione transferases on organophosphate insecticides applied to sylvatic $T$. infestans instar nymphs from Bolivia.

Previous studies have suggested that sylvatic populations are very important because of their possible role in resettling intradomiciliary environments. In addition, several reports have shown that these populations are more widely distributed than previously estimated (Noireau et al. 2005, Noireau 2009, Buitrago et al. 2010, Waleckx et al. 2012).

The possible development of resistance during the egg stage may contribute to failed control measures and should not be underestimated. Earlier studies demonstrated differences in the expression of resistance in eggs from pyrethroid-resistant populations (Toloza et al. 
2008). These authors evaluated the resistance of more developed (12-day-old) eggs compared to other insecticide effect studies of T. infestans eggs (Toloza et al. 2008, Visciarelli et al. 2011).

However, no investigators have analysed the pyrethroid susceptibility of eggs from sylvatic $T$. infestans populations, despite their possible importance in the recolonisation of intradomiciliary areas. Moreover, no previous studies on the contribution of pyrethroid esterases to pyrethroid susceptibility have been conducted in $T$. infestans eggs.

The aim of the present work was to study the susceptibility of eggs to deltamethrin and the contribution of pyrethroid esterases to deltamethrin degradation in sylvatic and domestic $T$. infestans populations.

\section{MATERIALS AND METHODS}

Insects - T. infestans were captured from domiciliary (-D) and sylvatic (-S) areas of Bolivia (department of Cochabamba, Viente de Octubre-S, department of Potosí, Kirus-Mayu-S and department of Tarija, El Palmar-D) and from Argentina (Salta province, La Pista-D) in 2009. Detailed geographic locations of the captured populations are shown in Table I.

Sylvatic T. infestans were captured from rock piles using mouse-baited sticky traps (Noireau et al. 1999). The insects were then reared in Bolivia. Eggs from the descendent populations were transported to the Research Center and Insect Pests (CIPEIN), Buenos Aires, Argentina, where subsequent generations were bred.

A susceptible reference strain (NFS) was derived from a domestic population captured in 2004 from Santiago del Estero, Argentina, in an area where insects were later successfully controlled with the pyrethroid insecticide deltamethrin. The insects from each population were reared in boxes at $28^{\circ} \mathrm{C}, 50-60 \%$ relative humidity (RH) and a photoperiod of 12:12 (L:D) h. One pigeon was provided each week to meet insect blood requirements (WHO 1994).

Chemicals - Technical grade deltamethrin (99\%) was purchased from Ehrestorfer (Augsburg, Germany). Analytical grade acetone was purchased from JT Baker (Estado de Mexico, Mexico). 7-hydroxycoumarin (7-OHC) (umbelliferone) was purchased from Sigma-Aldrich Co (St. Louis, MO, USA). Permethrinic acid [(1R, S)-cis-
( $98.7 \%$ cis, $0.9 \%$ trans)] was supplied by Chemotecnica (Buenos Aires, Argentina) and the thionyl chloride $\left(\mathrm{Cl}_{2}\right.$ SO, $99 \%$ ) and triethylamine (99\%) were purchased from Aldrich Chemical (Milwaukee, WI, USA). 7-coumaryl permethrate (7-CP) was synthesised in the CIPEIN using the method of Santo-Orihuela et al. (2006).

Topical application bioassays - Twelve-day-old second generation (F2) eggs were collected from adult rearing boxes and selected according to external morphological characteristics (orange coloured eggs and dark eye spots) as described by de Villar et al. (1979).

Groups of at least 10 eggs per concentration were fixed to a microscope slide with double-sided adhesive tape. Egg treatments were conducted individually using topical applications to the operculum of $0.2 \mu \mathrm{L}$ of serial deltamethrin dilutions in acetone using a $10 \mu$ L Hamilton syringe according to the method reported by Picollo et al. (1976). Final concentrations ranged from 0.0005-1 $\mathrm{mg} / \mathrm{mL}$ deltamethrin diluted in acetone. At least four different concentrations producing between 10-90\% mortality were used for each test. Each concentration, including the acetone only control (without insecticide), was replicated three times.

Following the topical application, eggs were incubated in a rearing cabinet (FOC-225E, Velp Scientifica, Milan, Italy) at $28^{\circ} \mathrm{C}, 50 \% \mathrm{RH}$ and a photoperiod of $12: 12$ (L:D) h. The estimated time for hatching control eggs under these laboratory conditions was 15 days. Mortality data were recorded six days after the topical application (3 days after the control eggs hatched).

Esterase activity - Pyrethroid esterase activity was determined by measuring the hydrolysis of 7-CP, a fluorescent substrate used to determine pyrethroid hydrolysis activity in individual insects (Santo-Orihuela et al. 2006, 2008). Eggs were collected and selected using the same criteria as those used in the bioassays. The eggs were cooled and each egg was homogenised in $220 \mu \mathrm{L}$ of phosphate buffer $(0.05 \mathrm{M}, \mathrm{pH} 7.2)$ using a plastic mortar and pestle. Because the 7-CP pyrethroid esterase method was conducted with the entire volume of each individual insect homogenate, these tests could not be replicated. The reaction was initiated by adding $10 \mu \mathrm{L}$ of 7-CP (in $3.5 \mathrm{mM} 2$-methoxyethanol) to $190 \mu \mathrm{L}$ of each homogenate. Incubation was conducted at $25^{\circ} \mathrm{C}$ for 33

TABLE I

Sylvatic (-S) and domiciliary (-D) populations

of Triatoma infestans analysed according to the collecting site in Bolivia and Argentina

\begin{tabular}{lcc}
\hline Site of collection & $\begin{array}{c}\text { Location } \\
\text { (locality/country) }\end{array}$ & Latitude/longitude \\
\hline Kirus-Mayu-S & Toro Toro/Potosí/Bolivia & $17^{\circ} 59^{\prime} \mathrm{S} 65^{\circ} 50^{\prime} \mathrm{W}$ \\
Veinte de Octubre-S & Cochabamba/Cochabamba/Bolivia & $17^{\circ} 29^{\prime} \mathrm{S} 66^{\circ} 07^{\prime} \mathrm{W}$ \\
El Palmar-D & El Palmar/Tarija/Bolivia & $17^{\circ} 02^{\prime} \mathrm{S} 64^{\circ} 12^{\prime} \mathrm{W}$ \\
La Pista-D & Salvador Mazza/Salta/Argentina & $22^{\circ} 4^{\prime} \mathrm{S} 63^{\circ} 41^{\prime} \mathrm{W}$ \\
NFS & Susceptible reference strain/Argentina & - \\
\hline
\end{tabular}


$\min$ at $\mathrm{pH}$ 7.2. The fluorescence was measured in a Fluoroskan Ascent Microplate Fluorometer (Thermo Scientific, Helsinki, Finland) and the results were analysed with Ascent (Thermo Scientific) and Microsoft Excel 2010 (Microsoft). Assays were conducted in black 96well polystyrene flat-bottomed microtitre plates (Perkin Elmer Life and Analytical Sciences) at $25^{\circ} \mathrm{C}$. $7-\mathrm{OHC}$ production was monitored at an excitation wavelength of $390 \mathrm{~nm}$ and an emission wavelength of $440 \mathrm{~nm}$; 7-CP pyrethroid esterase activity was measured $3 \mathrm{~min}$ for 33 min. The relative fluorescence units (RFU) were corrected for background hydrolysis and nonspecific substrate fluorescence and then transformed to picomoles/ min (activity units) using one calibration curve per replicate with dilutions of 7-OHC $(68.5,342.69,685.44$ and 1370.8 total picomoles/well).

Insect protein concentrations were quantified with a protein kit (Total Protein Kit, Sigma) based on the Bradford (1976) assay. The absorbance of the wells was determined using a spectrophotometric microplate reader equipped with $340 \mathrm{~nm}, 405 \mathrm{~nm}, 415 \mathrm{~nm}, 540 \mathrm{~nm}, 595$ $\mathrm{nm}$ and $655 \mathrm{~nm}$ wavelength filters (Model 680, BioRad Laboratories, Inc). Microplate Manager Software v. 5.2.1 (Bio-Rad Laboratories, Inc) was used to collect, analyse and output absorbance data from the Bio-Rad microplate readers.

Statistical analysis - Mortality data were processed with POLO Plus (LeOra Software 1987). Data from each T. infestans population were corrected using Abbott's formula (Abbott 1987) and were then pooled and analysed based on probit analysis (Litchfield Jr \& Wilcoxon 1949) to estimate the lethal dose (LD) (nanograms of insecticide per egg) that killed $50 \%$ of treated individuals $\left(\mathrm{LD}_{50}\right)$. $\mathrm{LD}$ ratios (LDRs) and 95\% confidence intervals (CI) for each population were calculated according to Robertson et al. (2007) by comparing the dose-response curves between studied populations and the reference strain NFS. Studied populations were considered different from the reference strain according to the criteria of Robertson et al. (2007) (Russell et al. 1977). According to these criteria, the LDR 95\% CI did not include the number 1.0.

The pyrethroid esterase activity values of eggs from different populations were expressed as picomoles of $7-\mathrm{OHC} \mathrm{pmol} / \mathrm{min} / \mathrm{mg}$ protein and these values were plotted on a scatter graph (Montella et al. 2007). Statistical analysis was performed using InStat v. 3.01 (Graphpad Software, San Diego, CA, USA). An ANOVA test was used to compare protein amounts among study populations and non-parametric Kruskal-Wallis and Dunn tests were used to compare 7-CP enzymatic activities per minute and per mg of protein among populations.

\section{RESULTS}

Figure and Table II show the toxicity of deltamethrin against 12-day-old T. infestans eggs from Bolivia and Argentina. The Bolivian population El Palmar-D showed the highest $\mathrm{LD}_{50}$ and LDR values $(27.80 \mathrm{ng} / \mathrm{egg}$ and 44.90, respectively), whereas Veinte de Octubre-S had the lowest values $(0.31 \mathrm{ng} / \mathrm{egg}$ and 0.50 , respectively).

The egg protein content results and statistical analyses from the study populations are shown in Table III.
The sylvatic populations, Kirus-Mayu-S and Veinte de Octubre-S, had higher protein contents than the domestic populations, El Palmar-D and La Pista-D and the reference strain (NFS). For this reason, all 7-CP activity values were corrected according to the mean protein content of the respective population and expressed per $\mathrm{mg}$ of protein.

The domestic populations El Palmar-D and La Pista-D from Bolivia and Argentina, respectively, had 7-CP activity values $(40.11$ and $36.64 \mathrm{pmol} / \mathrm{min} / \mathrm{mg}$ protein, respectively) similar to the values for reference strain NFS (34.92 $\mathrm{pmol} / \mathrm{min} / \mathrm{mg}$ protein) and were significantly different from the sylvatic populations Kirus-Mayu-S and Veinte de Octubre-S (27.49 and $22.69 \mathrm{pmol} / \mathrm{min} / \mathrm{mg}$ protein, respectively). These data are shown with their standard deviations and statistical analyses in Table III.

\section{DISCUSSION}

This study was the first analysis of pyrethroid esterase activities in eggs from sylvatic $T$. infestans using a specific substrate, namely, 7-CP (Santo-Orihuela et al. 2006). Previous studies have demonstrated the importance of sylvatic T. infestans and its possible role in recolonising insecticide-treated houses (Noireau 2009, Waleckx et al. 2012).

Most insecticides used in control campaigns are directed at larval and adult stages, but eggs are also subject to selection pressure. Therefore, it is relevant to evaluate the susceptibility of sylvatic $T$. infestans eggs.

In a previous study, Roca-Acevedo et al. (2011) analysed the toxicological profile of sylvatic T. infestans and found a slight increase in the $\mathrm{LD}_{50}$ and LDR for deltamethrin in the first instars of sylvatic populations in contrast with the reference strain, but no statistical evidence of a detoxifying enzyme contribution was reported.

In the present study, the eggs from domestic populations showed higher LDRs than the reference strain, indicating the development of embryonic resistance in these Bolivian and Argentine populations. These toxicological findings for eggs were in accordance with instar results demonstrated by Germano et al. (2010). These data indicate that eggs from domestic populations were resistant to deltamethrin, but no statistical contribution from 7-CP esterases was observed. However, deltamethrin resistance may be attributed to a reduced nerve sensitivity caused by a change in the action site (i.e., kdr and sodium channels) (Soderlund \& Knipple 2003, Fabro et al. 2012). The studied sylvatic populations showed $\mathrm{LD}_{50}$ and LDR values similar to the reference strain, but with higher protein contents and lower pyrethroid esterase activities; the increased protein content may be caused by differences in food sources and hosts under sylvatic conditions (Noireau et al. 2005, Cortez et al. 2007, Alvarado-Otegui et al. 2012). The toxicological pattern of sylvatic eggs in this study was very similar to the pattern of sylvatic instars described by Roca-Acevedo et al. (2011). The eggs in the present study had decreased 7-CP esterase activity in contrast with the reference strain and domestic population and a lower LDR than instars from previous studies (Roca-Acevedo et al. 2011). Toloza et al. (2008) demonstrated the existence of deltamethrin- 

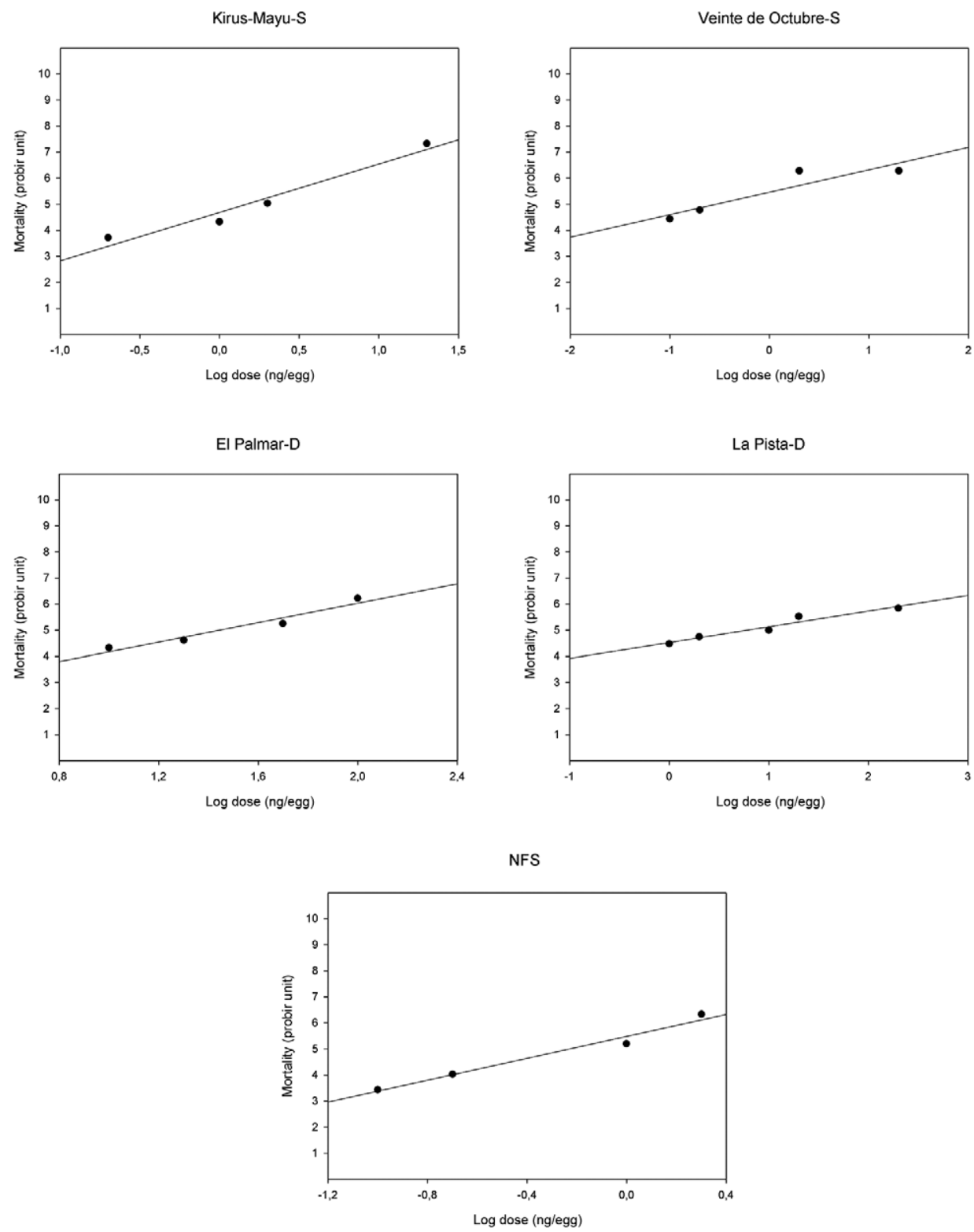

Graphics show mortality to deltamethrin (probit units) of eggs vs. logarithm of applied doses (nanograms per egg) for all studied Triatoma infestans populations and reference strain (NFS).

susceptible eggs and resistant first instar nymphs in domestic T. infestans populations from Sucre and Mataral (Bolivia). These authors attributed this phenomenon to an insecticide selection response to different field insecticide exposures and/or biological variations between Bolivian and Argentinean populations. Conversely, these sylvatic population findings might be explained by probable contact between sylvatic and domestic populations in neighbouring areas (Depickère et al. 2012).

One of the sylvatic populations studied in this work (Kirus-Mayu-S) showed a slight increase in LDR, suggesting a lower susceptibility to deltamethrin. This finding may be explained by the existence of naturally decreased susceptibility by the development of resistance resulting from exposure to insecticides used in crops and vector control campaigns or by contact and probable gene flow between geographically close sylvatic and domestic resistant populations. Additionally, a combination of these hypotheses may be possible (Lardeux et al. 2010, Depickère et al. 2012, Santo-Orihuela et al. 2013).

Based on the identification of different toxicological profiles according to different geographic areas for sylvatic and domestic $T$. infestans (Roca-Acevedo et al. 2011, Germano et al. 2012), it is possible to geographically define wild or domestic toxicological profiles. Although previous studies have suggested that the Andean valley in Bolivia represents the centre of origin and dispersal for T. infestans (Bargues et al. 2006, Cortez et al. 2010), an ancestral toxicological profile from that area may be unlikely. If this profile existed, it would be locat- 
TABLE II

Toxicity of deltamethrin against Triatoma infestans 12-days-old eggs from Bolivia and Argentina

\begin{tabular}{lcccccc}
\hline Population & & & & $\mathrm{LD}_{50}(\mathrm{ng}$ per egg $)$ & $\begin{array}{c}\text { LDR } \\
(95 \% \mathrm{CI})\end{array}$ \\
\hline Kirus-Mayu-S & $\mathrm{n}$ & Slope $\pm \mathrm{SE}$ & $\chi 2$ & $\mathrm{df}$ & $1.90(1.25-3.36)$ & $3.02(1.76-5.21)$ \\
Veinte de Octubre-S & 74 & $0.92 \pm 0.29$ & 1.61 & 2 & $0.31(0.06-0.94)$ & $0.50(0.15-1.60)$ \\
El Palmar-D & 88 & $1.84 \pm 0.45$ & 0.95 & 2 & $27.80(16.00-44.80)$ & $44.90(25.60-77.20)$ \\
La Pista-D & 80 & $0.76 \pm 0.20$ & 2.56 & 4 & $6.80(2.69-24.00)$ & $8.10(1.02-26.37)$ \\
NFS & 88 & $2.07 \pm 0.35$ & 1.26 & 2 & $0.61(0.43-0.91)$ & - \\
\hline
\end{tabular}

CI: confidence interval [calculated following Robertson et al. (2007)]; -D: domestic population; df: degrees of freedom; LD: lethal dose; LDR: LD ratios; -S: sylvatic population; SE: standard error; $\chi 2$ : chi-square. $\chi 2$ for probit analysis tests goodness-of-fit, in this case the values (responses) predicted by the statistical model adequately fit the data observed in the bioassay $(\mathrm{p}>0.05)$.

\section{TABLE III}

Means and standard deviations (SD) of protein content and activities of 7-coumaryl permethrate (7-CP) esterases

\begin{tabular}{|c|c|c|c|c|}
\hline Strain/population & $\mathrm{n}^{a}$ & $\begin{array}{l}\text { Mean protein content } \\
\pm \mathrm{SD} \text { ( } \mu \mathrm{g} \text { per insect) }\end{array}$ & $\mathrm{n}^{b}$ & $\begin{array}{c}\text { 7-CP activity } \pm \text { SD } \\
(\mathrm{pmol} / \mathrm{min} / \mathrm{mg} \text { protein })\end{array}$ \\
\hline Kirus-Mayu-S & 26 & $400.82( \pm 197.86)^{d}$ & 22 & $27.49( \pm 9.83)^{c, d}$ \\
\hline Veinte de Octubre-S & 43 & $350.83( \pm 131.85)^{d}$ & 43 & $22.69( \pm 9.41)^{c}$ \\
\hline El Palmar-D & 26 & $289.91( \pm 156.75)^{c}$ & 28 & $40.11( \pm 10.74)^{e}$ \\
\hline La Pista-D & 35 & $223.22( \pm 96.16)^{c}$ & 35 & $36.64( \pm 14.93)^{e}$ \\
\hline NFS & 24 & $265.26( \pm 118.42)^{c}$ & 32 & $34.92( \pm 13.67)^{d, e}$ \\
\hline
\end{tabular}

$a$ : number of eggs used from studied populations in protein assay; $b$ : number of eggs used from studied populations in 7-CP activity determination. Means of protein content followed by different letters $(c-e)$ are significantly different $(\mathrm{p}<0.05)$. TukeyKramer: $\mathrm{F}=3.71$. Values of activities of 7-CP esterases followed by different letters $(c-e)$ are significantly different $(\mathrm{p}<0.05)$ [Kruskal Wallis (KW) and Dunn's Multiple Comparisons Test]. KW statistic $=42.45$. SD: standard deviation.

ed in completely sylvatic areas, far from human activities. To date, the studied sylvatic populations have not been situated far from human influence and these populations may be under insecticide pressure or in contact with domestic T. infestans during their life cycle.

Although nonspecific esterases and pyrethroid esterases are likely to play a physiological role during the embryonic development of T. infestans, no studies have analysed this topic. Moreover, few reports have determined the occurrence of cholinesterases during egg neurogenesis in $T$. infestans and Triatoma patagonica (de Villar et al. 1979, Visciarelli et al. 2011). de Villar et al. (1980) and Wood et al. (1984) analysed the effects of parathion on cholinesterases and eserine-resistant esterases and the influence of parathion, malathion and fenitrothion on carboxylesterases in the developing embryo of T. infestans, respectively. These authors reported daily increases in enzymatic activities during embryonic development. For this reason, 7-CP activity comparisons among studied populations and the reference strain were conducted on the same day of embryonic development (12-day-old eggs).

Further studies in $T$. infestans eggs and nymphs should be performed to clarify the relevance of these geographically different wild and domestic toxicological and biochemical profiles in the development of resistance to pyrethroid and non-pyrethroid insecticides. These data might help to improve the effectiveness of chemical controls when applied directly to eggs, nymphs and adults.

\section{ACKNOWLEDGEMENTS}

To François Noireau and Mirko Rojas Cortez, for collecting sylvatic T. infestans in Bolivia, and to the NVBDCP of Argentina, for field sampling in Argentina.

\section{REFERENCES}

Abbott WS 1987. A method of computing the effectiveness of an insecticide. 1925. J Am Mosq Control Assoc 3: 302-303.

Alarico AG, Romero N, Hernández L, Catalá S, Gorla D 2010. Residual effect of a micro-encapsulated formulation of organophosphates and piriproxifen on the mortality of deltamethrin resistant Triatoma infestans populations in rural houses of the Bolivian Chaco region. Mem Inst Oswaldo Cruz 105: 752-756.

Alvarado-Otegui JA, Ceballos LA, Orozco MM, Enriquez GF, Cardinal MV, Cura C, Schijman AG, Kitron U, Gürtler RE 2012. The sylvatic transmission cycle of Trypanosoma cruzi in a rural area in the humid Chaco of Argentina. Acta Trop 124: 79-86.

Bargues MD, Klisiowicz DR, Panzera F, Noireau F, Marcilla A, Perez R, Rojas MG, O’Connor JE, Gonzalez-Candelas F, Galvão C, Jurberg J, Carcavallo RU, Dujardin JP, Mas-Coma S 2006. Origin 
and phylogeography of the Chagas disease main vector Triatoma infestans based on nuclear rDNA sequences and genome size. Infect Genet Evol 6: 46-62.

Bradford MM 1976. A rapid and sensitive method for the quantitation of microgram quantities of protein utilizing the principle of protein-dye binding. Anal Biochem 72: 248-254.

Buitrago R, Waleckx E, Bosseno MF, Zoveda F, Vidaurre P, Salas R, Mamani E, Noireau F, Brenière SF 2010. First report of widespread wild populations of Triatoma infestans (Reduviidae, Triatomine) in the Valleys of La Paz, Bolivia. Am J Trop Med Hyg 82: 574-579.

Carvajal G, Mougabure-Cueto G, Toloza AC 2012. Toxicity of nonpyrethroid insecticides against Triatoma infestans (Hemiptera: Reduviidae). Mem Inst Oswaldo Cruz 107: 675-679.

Cortez MR, Emperaire L, Piccinali R, Gürtler RE, Torrico F, Jansen AM, Noireau F 2007. Sylvatic Triatoma infestans (Reduviidae, Triatominae) in the Andean Valleys of Bolivia. Acta Trop 102: 47-54.

Cortez MR, Monteiro FA, Noireau F 2010. New insights on the spread of Triatoma infestans from Bolivia implications for Chagas disease emergence in the Southern Cone. Infect Genet Evol 10: 350-353.

de Villar MIP, Wood EJ, Zerba EN, de Licastro SA 1980. Cholinesterases and eserine-resistant esterases in the developing embryo of Triatoma infestans and its role as targets for inhibition in the ovicide action of parathion. Comp Biochem Physiol C 67: 55-59.

de Villar MIP, Zerba EN, Wood E, de Licastro S 1979. Neurogenesis and occurrence of cholinesterase in eggs of Triatoma infestans. Comp Biochem Physiol C 65: 65-70.

Depickère S, Buitrago R, Siñani E, Baune M, Monje M, Lopez R, Waleckx E, Chavez T, Brenière SF 2012. Susceptibility and resistance to deltamethrin of wild and domestic populations of Triatoma infestans (Reduviidae: Triatominae) in Bolivia: new discoveries. Mem Inst Oswaldo Cruz 107: 1042-1047.

Dias JCP, Schofield CJ 2007. Introducción. In M Rojas Cortéz, Triatominos de Bolivia y la enfermedad de Chagas, Ministerio de Salud y Deportes, La Paz, p. 3-5.

Dias JCP, Silveira AC, Schofield CJ 2002. The impact of Chagas disease control in Latin America: A Review. Mem Inst Oswaldo Cruz 97: 603-612.

Fabro J, Sterkel M, Capriotti N, Mougabure-Cueto G, Germano M, Rivera-Pomar R, Ons S 2012. Identification of a point mutation associated with pyrethroid resistance in the para-type sodium channel of Triatoma infestans, a vector of Chagas's disease. Infect Genet Evol 12: 487-491.

Germano MD, Acevedo GR, Cueto GAM, Toloza AC, Vassena CV, Picollo MI 2010. New findings of insecticide resistance in Triatoma infestans (Heteroptera: Reduviidae) from the Gran Chaco. J Med Entomol 47: 1077-1081.

Germano MD, Santo-Orihuela PL, Acevedo GR, Toloza A, Vassena C, Picollo M, Cueto GM 2012. Scientific evidence of three different insecticide-resistant profiles in Triatoma infestans (Hemiptera: Reduviidae) populations from Argentina and Bolivia. J Med Entomol 49: 1355-1360.

Gurtler RE, Kitron U, Cecere MC, Segura EL, Cohen JE 2007. Sustainable vector control and management of Chagas disease in the Gran Chaco, Argentina. Proc Natl Acad Sci USA 104: 16194-16199.

Lardeux F, Depickère S, Duchon S, Chavez T 2010. Insecticide resistance of Triatoma infestans (Hemiptera, Reduviidae) vector of Chagas disease in Bolivia. Trop Med Int Health 15: 1037-1048.

Litchfield Jr JT, Wilcoxon F 1949. A simplified method of evaluating dose-effect experiments. J Pharmacol Exp Ther 96: 99-113.

Montella IR, Martins AJ, Viana-Medeiros PF, Lima JBP, Braga IA, Valle D 2007. Insecticide resistance mechanisms of Brazilian Ae- des aegypti populations from 2001 to 2004. Am J Trop Med Hyg 77: 467-477.

Noireau F 2009. Wild Triatoma infestans, a potential threat that needs to be monitored. Mem Inst Oswaldo Cruz 104 (Suppl. I): 60-64.

Noireau F, Cortez MGR, Monteiro FA, Jansen AM, Torrico F 2005. Can wild Triatoma infestans foci in Bolivia jeopardize Chagas disease control efforts? Trends Parasitol 21: 7-10.

Noireau F, Flores R, Vargas F 1999. Trapping sylvatic Triatominae (Reduviidae) in hollow trees. Trans R Soc Trop Med Hyg 93: 13-14.

Picollo MI, Vassena CV, Santo-Orihuela PL, Barrios S, Zaidemberg M, Zerba E 2005. High resistance to pyrethroid insecticides associated with ineffective field treatments in Triatoma infestans (Hemiptera: Reduviidae) from northern Argentina. J Med Entomol 42: 637-642.

Picollo MI, Wood E, Zerba EN, Licastro SA, Rúveda MA 1976. Laboratory test for measuring toxicity of insecticides in Triatoma infestans, Klug. Acta Bioquim 10: 67-70.

Robertson J, Russel R, Preisler H, Savin N 2007. Pesticide bioassays with arthropods, 2nd ed., CRC Press, Boca Ratón, 127 pp.

Roca-Acevedo G, Cueto G, Germano M, Santo-Orihuela P, Cortez MR, Noireau F, Picollo M, Vassena C 2011. Susceptibility of sylvatic Triatoma infestans from Andeans Valleys of Bolivia to deltamethrin and fipronil. J Med Entomol 48: 828-835.

Russell R, Robertson J, Savin N 1977. POLO: a new computer program for probit analysis. Bulletin of the ESA 23: 209-213.

Santo-Orihuela PL, Carvajal G, Picollo MI, Vassena CV 2013. Toxicological and biochemical analysis of the susceptibility of sylvatic Triatoma infestans from the Andean Valley of Bolivia to organophosphate insecticide. Mem Inst Oswaldo Cruz 108: 790-795.

Santo-Orihuela PL, Picollo MI 2011. Contribution of general esterases to pyrethroid resistant Triatoma infestans (Hemiptera: Reduviidae) from Argentina and Bolivia. Acta Toxicol Argent 19: 32-40.

Santo-Orihuela PL, Picollo MI, Audino PG, Barrios S, Zerba E, Masuh H 2006. 7-coumaryl permethrate and its cis- and transisomers as new fluorescent substrates for examining pyrethroidcleaving enzymes. Pest Manag Sci 62: 1039-1044.

Santo-Orihuela PL, Vassena CV, Zerba EN, Picollo MI 2008. Relative contribution of monooxygenase and esterase to pyrethroid resistance in Triatoma infestans (Hemiptera: Reduviidae) from Argentina and Bolivia. J Med Entomol 45: 298-306.

Schofield CJ, Jannin J, Salvatella R 2006. The future of Chagas disease control. Trends Parasitol 22: 583-588.

Soderlund DM, Knipple DC 2003. The molecular biology of knockdown resistance to pyrethroid insecticides. Insect Biochem Mol 33: 563-577.

Toloza AC, Germano M, Cueto GM, Vassena C, Zerba E, Picollo MI 2008. Differential patterns of insecticide resistance in eggs and first instars of Triatoma infestans (Hemiptera: Reduviidae) from Argentina and Bolivia. J Med Entomol 45: 421-426.

Visciarelli E, Chopa CS, Picollo MI, Ferrero A 2011. Cholinesterase activity during embryonic development in the blood-feeding bug Triatoma patagonica. Med Vet Entomol 25: 297-301.

Waleckx E, Depickère S, Salas R, Aliaga C, Monje M, Calle H, Buitrago R, Noireau F, Brenière SF 2012. New discoveries of sylvatic Triatoma infestans (Hemiptera: Reduviidae) throughout the Bolivian Chaco. Am J Trop Med Hyg 86: 455-458.

WHO - World Health Organization 1994. Protocolo de evaluación de efecto insecticida sobre Triatominos. Acta Toxicol Argent 2: 29-32.

Wood EJ, de Villar MIP, Zerba EN 1984. Role of a microsomal carboxylesterase in reducing the action of malathion in eggs of Triatoma infestans. Pestic Biochem Physiol 23: 24-32. 